\title{
紅茶タンニン中の窒素の存在
}

\author{
静岡大学農学部 中 林 敏 郎
}

\section{Nitrogen in Black Tea Tannin}

By Toshio NAKabaYASHI

\section{1.まえがき}

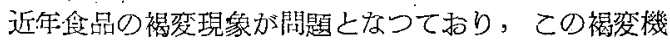
構は主にカルポニル化合物とアミノ酸との間と起客いる ゆるアミノーカルポニル反心仙よつて，メラうイド色菜が 珠成されるためといわれている。通常の食品の場合汇 は，主還元䊒のカルボニル基がこの反応に関与するの であるが，ポリフェノール類の最初の腰化生成物である キノン類も広巍の活性刃ルボニル化合物と考えられるの で, このキノンとアミノ酸との間にもアミノーカルボニル 反结が起つて，メシノイド色素学形成することは当然予 想されるところである。

例えばMASoN はポリフェノールオキシダーゼの存在

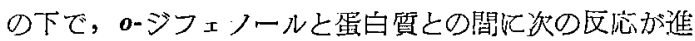
行すると塟じている。

1. catechol $+\mathrm{O} \rightarrow 0$-quinone $+\mathrm{H}_{2} \mathrm{O}$

2. $o$-quinone + amine $\rightarrow$ aminohydroquinone

3. aminohydroquinone $+o$-quinone $\rightarrow$ aminoquinone + catechol

又 HACKMAN 等はカテコールは酸化酳素や酸化成の存 在の下で,アミンやアミノ酸と反応して<smiles></smiles><smiles>O=C(O)CNC1C(=O)C=CC1=O</smiles>

を生成することを報じ，著者も林㮩果肉の褐変現象の研 究において，ポリフェノールオキシダーぜはアミン頻を: 酸化しないが，これに少量のカテコールを添加すると，

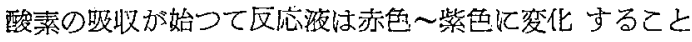
を認め，これはのーキノンとアミンとが綕合したためであ ろうと推定した。

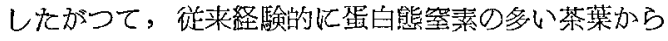
は皇質の紅菜加得られないといわれている原因の一部

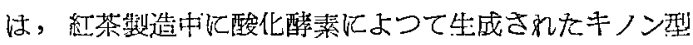
タンニンと，アミノ酸や蛋白質との間のアミノーカルボニ

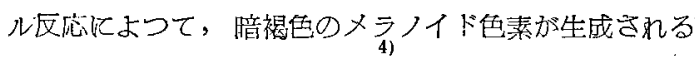
ためであり，先に大島及び著者が分別した紅茶タンニン の3 成分のうち，秋及び味を損う酸化重合タンニンが このメラノイド色菜に相当すると推定される。
この問題は紅茶の品質に大きな影響をもつと考えられ るので, 著者は紅茶タンニンの各部分について 更に分別 精製して分析を行い，その中の窒素の存在を検謿するこ とにようてこの問題を明ら加するとととした。

\section{2. 和茶タンニンの分別精製}

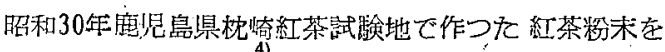
用小，先江行六分別法考政良して、紅茶タンニンを分別 し，FRIEDLICH の改良溚によるケルダール法で坴素を 定量しつつ, タンニンの 各部分の窒蒵含量が一定又は無 視し得る程度になるまで, 第 1 表のよう精製を行つ to

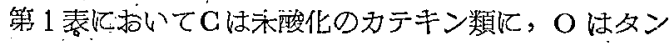
二ン酸化物に， $P_{1}, P_{2}$ は酸化雷合物他相当するか゚， C及 び○はその望素含量がいずれる微量であるので，メラノ イド色素倠該当しない。そ己で $\mathrm{P}_{1}$ 及び $\mathrm{P}_{2}$ について検 討を行うこととした。

\section{3. $P_{1} の$ 分 析}

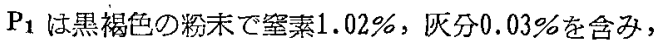
水に怟とんど不溶，アルコール更びアルカリに溶けて暗 褐色を是する。 $\mathrm{P}_{1}$ を $5 \%$ 塩酸で5 踏間加水分解して分解 生成物をぺーパークロマトグラフ法でしらべると，第 1

第 1 図 $P_{1}$ 加水分解物のペーパー クロマトグラム $\left(\mathrm{FeCl}_{3}\right.$ 刍色)

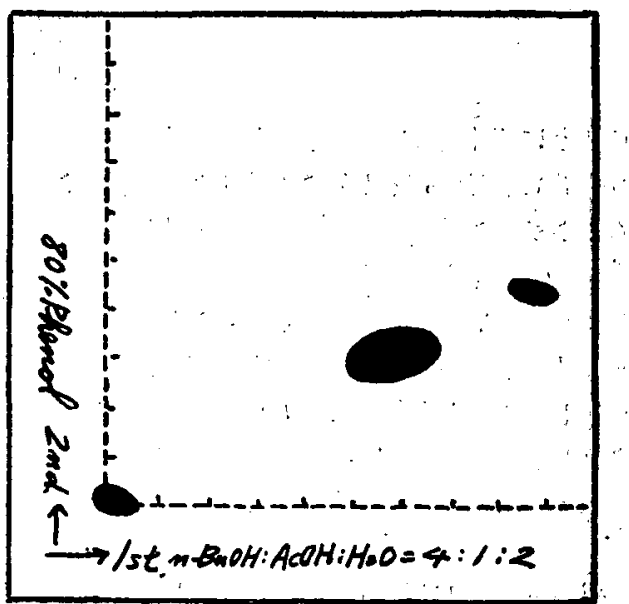




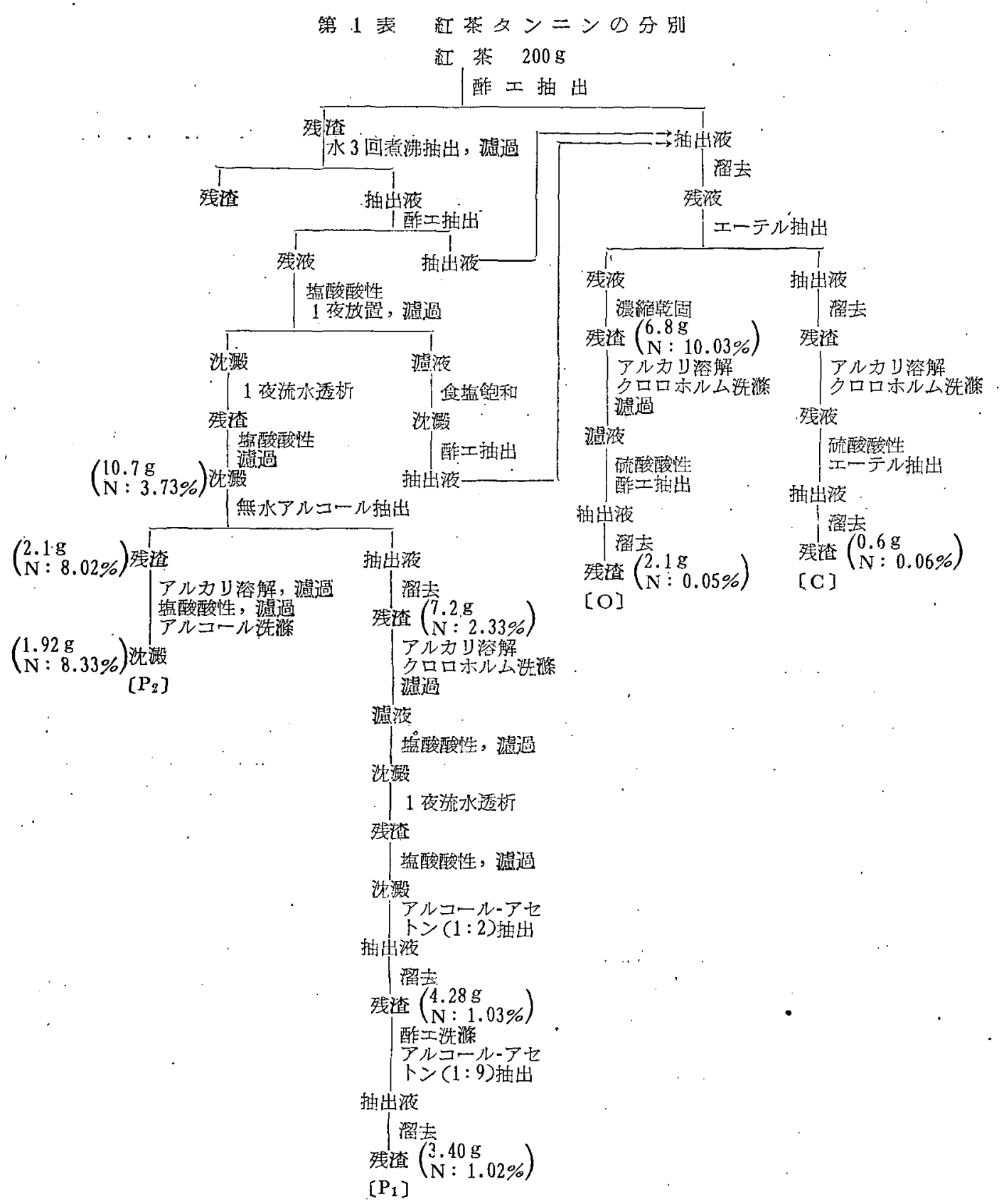

因のように篮化第二鉄で暗青色保呈色する3 個のスポッ トが検出されるが，他にニンヒドリン，ドラケンドルフ

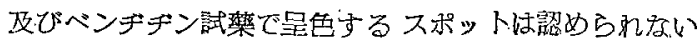
から，P1の窒素は蛋白質，アミノ酸やカフェインに由来 したものでないてと汃判る。特にニンヒドリンで反怘し ないことから，P、の害素は第 2 級以上の形態でタンニン に結合していると考えられ，したがつて $P_{1}$ はアミノキ ノンの酸化重合物であらうと推定される。

\section{4. $P_{2}$ の 㞣 析}

$P_{2}$ ほ裀色の軽い㹊末で窒索8.33\%，灰分3.6\%を含み，
憼水にやや可溶, アルコールに不溶, アルカリに悪けて 瞕褐色を星す。 $5 \%$ 篮酸仗よる分解物のペーパークロマ トダラムは，管 2 図のように壏化第二鉄，ニンヒドリン 及びベンデデン試藥でそれぞれ数堌 のスポットが检出さ れ，ベルトラン比法で測定すればグルコースとして17.7 \%の還元性物質が定量れさる。この結果より， $\mathrm{P}_{2}$ は蛋白 質約 $50 \%$ ，ヘミセルローズ等の炭水化物約 $20 \%$ ，タンニ ン約20\%よりなるととが推定され，蛋白質の一部にタン ニンがアミノキノン型们固く結合し，乙れにへミセルロ ーズとタンニンとの結合物が瞇在していると考えられ る。 
第 2 図 $\mathrm{P}_{2}$ 分解物のペーパークロマトグラム

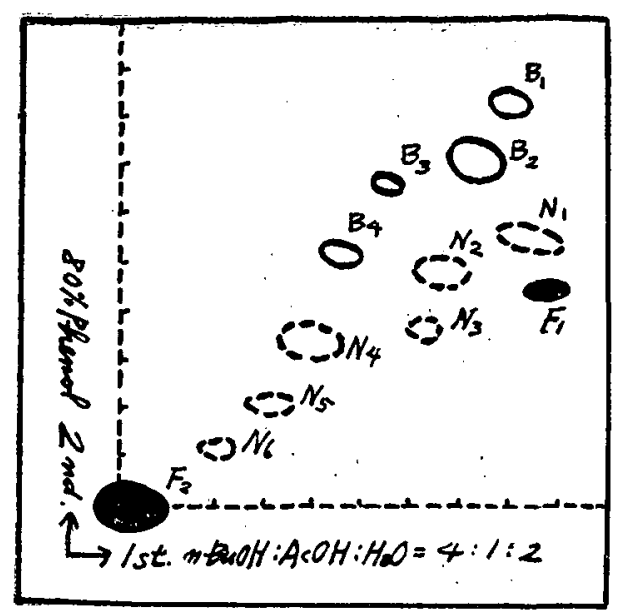

$\mathrm{F}_{1} \sim_{2}: \mathrm{FeCl}_{3}$ 陽性スポット

$\mathrm{N}_{1} \sim_{0}:$ ニンヒドリン陽性スポット

$\mathrm{B}_{1}$ 4: ベンデデン陽性スポット

\section{5.むすび}

以上の㬰験結果から，址茶タンニン中の酸化需合物は アミノキノンの酸化重合物と, 蛋白ータンニン結合物とよ

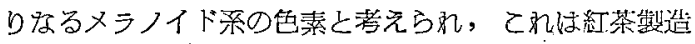

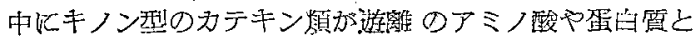
結合し，乙れが酸化重合して生成される。

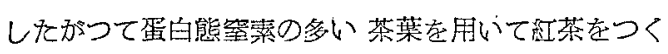
る踏は，かかるメラノイド色瑟の形成が進行して腤褐色 を增し，不溶性タンニン索增加する等，紅获品翼の低下 をもたらすようになると推定される。

\section{6. 参考文 献}

1) Mason, H. S.: Nature, 175, 771 (1955).

2) HACKMAN, R. H. and A. R. ToDD: Biochem. J., 55, 631 (1953).

3) 中林敏郎：農化，28，212 (1954).

4) 大島度京, 中林敏郎, 石橋幸枝: 農化, 28, 269, 614 (1954).

5) Friadrich, A.: Ztschr. Physiol. Chem., 216, 68 (1933).

\section{Summary}

The purified two tannin fractions, which were formed by the oxidation and polymerization of catechins, were isolated from black tea. One fraction contained $1.02 \%$ of nitrogen and the other $8.33 \%$.

It is, therefore, supposed that the oxidized quinone-type tannin made a melanoidin pigment as the result of the combination with amino acid and protein and spoiled the quality of' black tea.

(Feb. 21, 1956) 